\title{
Exploration and morphologic variation of Iris wild species with ornamental potential
}

\author{
Elham Asgari $^{1}\left(\mathbb{D}\right.$, Mina Taghizadeh ${ }^{1 *}(\mathbb{D})$, Ahmadreza Abbasifar ${ }^{1} \mathbb{C}$ \\ ${ }^{1}$ Arak University, Faculty of Agriculture and Environmental Science, Department of Horticultural Engineering, Arak, Iran
}

\begin{abstract}
Nowadays, the flower industry is growing so fast that its development requires introducing new varieties to the flower market. Iran is the habitat of numerous species of wild plants that are among the valuable genetics in the breeding process. The identification of native Iris species, investigation of morphological diversity, and distribution method have a significant effect on the introduction of this flower as new and superior cultivars cut flower and bedding plant. The documentation of the most important habitats of Iris in Arak province, identification of morphological characteristics and correlation determination of morphological traits are the most important aims of this research. The results showed that there is a correlation between some of the traits. The highest positive correlation was related to the height of flower and length of the leaf, length of the flowering stem and the length of the leaf and the height of the flower and the length of the flowering stem. The ecotypes of Iris sp. were divided into six groups. Based on the results of the cluster diagram, the bulbous species were separated from rhizome species. Generally, due to the color diversity of Iris sp. and unique beauty of the flowers and the resistance of the native species, they can be used as native foundations. Due to the prominent traits such as high durability of Iris meda, odor of I. hymernospatha Subsp. leptoneura and color diversity of I. persica, I. songarica and height of I. spuria, they can be used to introduce new ornamental species. Iris spuria is the most suitable genotype because of the high height, large flower, high durability, and beautiful flower.
\end{abstract}

Keywords: endemic plants, flowers, germplasm, Iran, variation.

\section{Resumo}

Exploração e variação morfológica de espécies selvagens de Iris com potencial ornamental

A indústria de flores está crescendo tão rápido que seu desenvolvimento exige a introdução de novas variedades no mercado de flores. O Irã é o habitat de numerosas espécies de plantas selvagens que estão entre as valorizadas geneticamente no processo de melhoramento. A identificação de espécies nativas de Iris, pesquisas de diversidade morfológica e o método de distribuição têm efeito significativo na introdução de cultivares superiores como flor de corte e forração. A documentação dos habitats mais importantes de Iris na província de Arak, identificação de características morfológicas e determinação de correlação de características morfológicas são os objetivos mais importantes desta pesquisa. Os resultados mostraram que existe a correlação entre algumas das características. A correlação mais positiva foi relacionada ao tamanho da flor e comprimento da folha, comprimento da haste floral e comprimento da folha, e tamanho da flor e comprimento da haste floral. Os ecótipos de Iris sp. foram divididos em seis grupos. Com base nos resultados do diagrama de agrupamento (cluster), as espécies bulbosas foram separadas das espécies com rizoma. Geralmente, por causa da diversidade de cores de Iris sp. e a beleza única das flores e a resistência das espécies nativas, estas podem ser usadas como base nativa. Devido a características proeminentes, como alta durabilidade de Iris meda, aroma de I. hymernospatha Subsp. leptoneura e diversidade de cores de I. persica, I. songarica e altura de I. spuria, podem ser usados para introduzir novas espécies ornamentais. Iris spuria é o genótipo mais adequado devido à maior altura, tamanho da flor, elevada durabilidade e beleza da flor.

Palavras-chave: plantas endêmicas, flores, germoplasma, Irã, variação.

\section{Introduction}

Iran is the habitat of numerous species of wild plants that are among the valuable genetics in the breeding process and supports a great share of exotic and/or endemic plant genera and species (Kiani et al., 2017; Parvin and Alizadeh,
2017). Generally, in addition to being as infrastructure for agricultural development, the genetic plant resources are a source of genetic compatibility and also a defense against challenging environmental issues (Parvin and Alizadeh, 2017). Furthermore, for the production of plants with enhanced quality, the presence of species with attractive

*Corresponding author: m-taghizadeh@araku.ac.ir 
appearance and desired features has been emphasized in the improvement of ornamental plants. Nowadays, the flower industry is growing so fast that its development requires introducing new varieties to the flower market. One of the important purposes of this industry is to improve the product features such as high flower production ability, flowering uniformity, resistance to diseases and pests as well as flower vase life (Noman et al., 2017). To Know different behavior of plants in the growth period and flowering phenology, not only helps carefully plan for the fertilization and harvesting, but also saves expenses and energy consumption in the flowering period (Van Der Ploeg and Heuvelink, 2006). Iris species have large colorful flowers and are distributed in the Northern Hemisphere from Europe to the Middle East (Yang et al., 2017). Iris sp. grow near springs, rivulets, uncultivable deserts and calcareous soils and some of the species are specific to the cliff and rock regions (Kandemir et al., 2019). Different species of Iris are used not only as ornamental flowers, but also as one of the resources that produce perfumes in the cosmetics and beauty industry (Demir and Çelikel, 2018). There is a very wide diversity of Iris sp. and new cultivars can be obtained by hybridization techniques. Iris sp. is an ornamental plant used in landscape and cut flowers. Producing new cultivars of Iris is the main purpose in the programs of cultivation and production of ornamental plants (Demir and Çelikel, 2018). In addition to the ornamental aspect, Iris sp. has other features. The researchers showed that some of the Iris species have the capability of the uptake of heavy metals which can be used in the phytoremediation and remediation of heavy metals (Singaba et al., 2016). During the last three decades, the classical methods have been increasingly performed for evaluating the genetic diversity with molecular methods, such as anatomy, morphology and physiology (Mosa et al., 2019). There are different methods for investigating the diversity among plant species, and one of the low-cost and widely-used methods is to investigate the physiological or morphological variations. Although morphology is more affected by environmental conditions than molecular diversity, it is used in different plants (Hosseini et al., 2017). The morphological features can show the diversity among the population. Wendelbo and Mathew (1975) introduced 45 species of Iris where the 24 species and subspecies are naturally distributed in Iran and 10 species are endemic in Iran. In this colorful flora, Ghahraman introduced 21 native species of Iris sp. (Azimi et al., 2019). In another research, Azimi et al. (2011) evaluated the existing genetic diversity in 18 species of Iris sp. collected from different provinces of Iran by 10 random primers of RAPD in the polymerase chain reaction. According to RAPD data, cluster analysis divided different 18 species into 6 groups. The results of study on the morphological characteristics of 12 populations from three Iris species with Iranian and German origin showed that the studied populations of Iris were different considering most of the qualitative and quantitative morphological traits. These superior populations were introduced to improve existing hybrid and species of Iris. To identify the Iris species of Hamedan province, a study was conducted by Khakizadeh and Ghanavati (2010). The collected samples consisted of 9 species: I. reticulata M.B., I. songarica Schrenk, I. spuria L., I. humenospatha subsp. Leptoneura Mathew \& Wendelbo, I. barnumae Baker \& Foster, I. meda Stupe, I. pseudocaucasica Grossh, I. germanica L., I. acutiloba C.A. Mey. In another study, the genotype of wild Iris species including I. fosteriana, I. songarica and I. kopetdaghensis were collected from different areas of Khorasan province to investigate the genetic diversity of some Iris sp. using the ISSR marker and 16 primers. The investigation of 6 ISSR molecular markers among 126 reproduced bands showed 119 polymorphism bands $(94 / 4 \%)$. The results of this research showed that this marker can distinguish the species and genotypes of the population in this species (Attari et al., 2016). The researchers studied the morphological traits of Oncusyclus subspecies Iris to determine the classification relations and morphology. The vegetative and reproductive characteristics related to 42 populations (9 species) were measured and it was concluded that the natural selection (including weather conditions and geographical separation) caused the differentiation among the population. They divided the mentioned groups into two main groups by cluster analysis where the first group includes the populations with dark color and the second group includes the population with bright color (Yuval et al., 2002). Rahimi et al. (2011) studied the Iran's endemic Iris. The morphological characteristics of 24 accessions belonging to 5 species were analyzed in the flowering season. The researchers divided the studied Iris into three main groups. In another research, the anatomic features of the leaves of eight species of Iris were compared and their relationships were determined. The species I. pamphylica, I. histrioides, I. celikii, I. danfordiae, I. histrio ssp., I. pamphylica, I. histrioides, I. celikii, histrio ssp., I. aintabensis, I. bakeriana, I. aintabensis and I. histrio are exclusive native to Turkey (Kandemir, 2019).

Markazi province is the suitable place for conducting this research because of having a mountain environment and a suitable climate for Iris species. Hence, the documentation of the most important habitats of Iris in this province, identification of morphological characteristics., and correlation determination of morphological traits are the most important aims of this research.

\section{Materials and Methods}

\section{Study Area}

This study was conducted in Markazi province in western Iran (Figure 1). To investigate the morphology of wild genotypes according to the geographical distribution, different regions including the mountains of different areas were studied. The areas were located at $33-37^{\circ}$ North latitude and $40-50^{\circ}$ East longitude and 1700-2500 $\mathrm{m}$ height above sea level. The average annual air temperature over 40 years 
in Arak is $13.8{ }^{\circ} \mathrm{C}$, and the average annual rainfall in the same period is $341.7 \mathrm{~mm}$. The average annual air humidity is $58.46 \%$, which indicates the dry air. The Arak region has cold and humid winters and hot and dry summers, and the winters usually last for a long period of 4 to 6 months. Spring and autumn are short seasons. Arak has a semi-arid climate according to the De Martone method, and it is in the dry climate of the Embereger climate zone (MPMO).

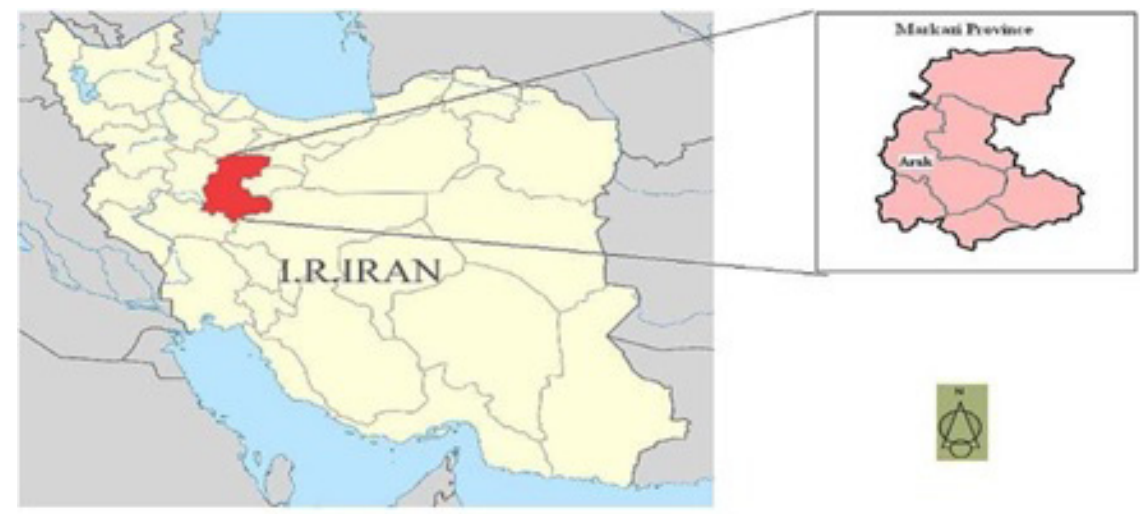

Figure 1. Location of study areas in Arak, Markazi province, Iran

\section{Sampling method}

The data were collected from the end of March 2017 to the end of June 2018. The main purpose was to identify and evaluate the qualitative and phonological characteristics of germplasm collection in this species. For this purpose, the sites located in the rangelands, meadows, open plains, foothills, heights and rivers were carefully visited. The sampling was started from the areas that had early spring and had species with early flowering. Due to the lack of accurate maps from the vegetation site, collecting the paths was started with the exploration from the climbers and native people. To avoid possible vegetative similarities, the samples were randomly chosen and marked at intervals of 5-20 m apart (Hosseini et al., 2018; Schai-Braun et al., 2020). GPS device was used to record the exact location of sampling (Table 1).

Table 1. Flowering period, propagation and geographical location of the species identified with ornamental potential in Markazi province, Iran.

\begin{tabular}{|c|c|c|c|c|c|}
\hline Species & Family & $\begin{array}{l}\text { Period of } \\
\text { flowering }\end{array}$ & propagation & Habitat & Geographic coordinates \\
\hline Tulipa biflora & Liliaceae & March- April & Seed and Bulb & $\begin{array}{c}\text { Sorkheh, Shahbaz } \\
\text { mountain, Nazm } \\
\text { Abad }\end{array}$ & $\begin{array}{c}\text { Latitude: } 34^{\circ} 22^{\prime}-34^{\circ} 34^{\prime} \\
\text { Longitude: } 40^{\circ} 40^{\prime}-49^{\circ} 44^{\prime} \\
\text { Altitude: } 2696\end{array}$ \\
\hline T. armena & Liliaceae & April & Seed and Bulb & Aseman valley & $\begin{array}{l}\text { Latitude: } 37^{\circ} 86^{\prime} \\
\text { Longitude: } 35^{\circ} 48^{\prime} \\
\text { Altitude:2135 }\end{array}$ \\
\hline T. orphanidea & Liliaceae & April & Seed and Bulb & Aseman valley & $\begin{array}{l}\text { Latitude: } 37^{\circ} 86^{\prime} \\
\text { Longitude: } 35^{\circ} 48^{\prime} \\
\text { Altitude: } 2135\end{array}$ \\
\hline T. montana & Liliaceae & April- May & Seed and Bulb & Aseman valley & $\begin{array}{c}\text { Latitude: } 37^{\circ} 86^{\prime} \\
\text { Longitude: } 35^{\circ} 48 \\
\text { Altitude: } 2141\end{array}$ \\
\hline T. sylvestris & Liliaceae & April & Seed and Bulb & Sorkheh mountain & $\begin{array}{l}\text { Latitude:34 } 34^{\prime} \\
\text { Longitude: } 40^{\circ} 40^{\prime} \\
\text { Altitude: } 1879\end{array}$ \\
\hline T. violacea & Liliaceae & April & Seed and Bulb & Nazm Abad & $\begin{array}{l}\text { Latitude: } 34^{\circ} 2^{\prime} \\
\text { Longitude: } 49^{\circ} 44^{\prime} \\
\text { Altitude: } 2696\end{array}$ \\
\hline $\begin{array}{l}\text { Fritillaria } \\
\text { imperialis }\end{array}$ & Liliaceae & April & Seed and Bulb & Aseman valley & $\begin{array}{c}\text { Latitude: } 37^{\circ} 86^{\prime} \\
\text { Longitude: } 35^{\circ} 48 \\
\text { Altitude:2140- } 2203\end{array}$ \\
\hline
\end{tabular}


Table 1. cont.

\begin{tabular}{|c|c|c|c|c|c|}
\hline F. persica & Liliaceae & April & Seed and Bulb & Aseman valley & $\begin{array}{c}\text { Latitude: } 37^{\circ} 86^{\prime} \\
\text { Longitude: } 35^{\circ} 48^{\prime} \\
\text { Altitude: } 2140-2203\end{array}$ \\
\hline F. zagrica & Liliaceae & March- April & Seed and Bulb & Nazm Abad & $\begin{array}{l}\text { Latitude: } 34^{\circ} 2^{\prime} \\
\text { Longitude: } 49^{\circ} 44^{\prime} \\
\text { Altitude: } 2696\end{array}$ \\
\hline Iris songarica & Iridaceae & April- May & $\begin{array}{l}\text { Seed and } \\
\text { Rhizome }\end{array}$ & $\begin{array}{l}\text { Amr abad, Amir kabir } \\
\text { Township, Aman abad }\end{array}$ & $\begin{array}{l}\text { Latitude: } 34^{\circ} 14^{\prime}-34^{\circ} 86^{\prime} \\
\text { Longitude: } 50^{\circ} 70^{\prime}-50^{\circ} 73^{\prime} \\
\text { Altitude: } 1771-1730\end{array}$ \\
\hline I. meda & Iridaceae & April- May & $\begin{array}{l}\text { Seed and } \\
\text { Rhizome }\end{array}$ & Tafresh & $\begin{array}{l}\text { Latitude:34 } 38^{\prime} \\
\text { Longitude:50 } 49^{\prime} \\
\text { Altitude: } 1909\end{array}$ \\
\hline I. hymenospatha & Iridaceae & March & Seed and Bulb & $\begin{array}{l}\text { Sorkheh, Shahbaz } \\
\text { mountain, Daen, } \\
\text { Tafresh } \\
\text { Aseman valley }\end{array}$ & $\begin{array}{l}\text { Latitude: } 33^{\circ} 25^{\prime}-34^{\circ} 38^{\prime} \\
\text { Longitude: } 40^{\circ} 40^{\prime}-50^{\circ} 49^{\prime} \\
\text { Altitude: } 2507-1896\end{array}$ \\
\hline I. persica & Iridaceae & March & Seed and Bulb & $\begin{array}{l}\text { Sorkheh, Shahbaz } \\
\text { mountain, Daen, } \\
\text { Tafresh, Hazaveh, } \\
\text { Haftad gholeh, Daen, } \\
\text { Tafresh, Hazaveh, } \\
\text { Ghayenaroogh, } \\
\text { Cheshmeh } \\
\text { sarab,Aseman valley }\end{array}$ & $\begin{array}{l}\text { Latitude: } 33^{\circ} 25^{\prime}-34^{\circ} 78^{\prime} \\
\text { Longitude } 40^{\circ} 40^{\prime}-50^{\circ} 49^{\prime} \\
\text { Altitude: } 2487-1788\end{array}$ \\
\hline I. spuria & Iridaceae & May- June & $\begin{array}{l}\text { Seed and } \\
\text { Rhizome }\end{array}$ & Far village & $\begin{array}{l}\text { Latitude: } 34^{\circ} 38^{\prime} \\
\text { Longitude: } 50^{\circ} 48^{\prime} \\
\text { Altitude: } 2492\end{array}$ \\
\hline $\begin{array}{c}\text { Gladiolus } \\
\text { atroviolaceus }\end{array}$ & Iridaceae & April- May & Seed and Bulb & Aghil abad, Enaj & $\begin{array}{l}\text { Latitude: } 33^{\circ} 59^{\prime}-34^{\circ} 12^{\prime} \\
\text { Longitude: } 49^{\circ} 21^{\prime}-49^{\circ} 38^{\prime} \\
\text { Altitude: } 1878-1967\end{array}$ \\
\hline $\begin{array}{l}\text { Colchicum } \\
\text { autumnal }\end{array}$ & Colchicaceae & October & Seed and Corm & $\begin{array}{l}\text { Aseman valley, } \\
\text { Nazm abad, Sorkheh, } \\
\text { Shahbaz mountain, } \\
\text { Ghayenaroogh }\end{array}$ & $\begin{array}{c}\text { Latitude: } 33^{\circ} 25^{\prime}-37^{\circ} 86^{\prime} \\
\text { Longitude } 40^{\circ} 40^{\prime}-49^{\circ} 44^{\prime} \\
\text { Altitude: } 2400\end{array}$ \\
\hline $\begin{array}{c}\text { Crocus } \\
\text { cartwrightianus }\end{array}$ & Iridaceae & March & Seed and Bulb & $\begin{array}{c}\text { Sorkheh, Shahbaz } \\
\text { mountain }\end{array}$ & $\begin{array}{c}\text { Latitude: } 33^{\circ} 25^{\prime}-34^{\circ} 34^{\prime} \\
\text { Longitude: } 40^{\circ} 40^{\prime}-49^{\circ} 25^{\prime} \\
\text { Altitude: } 2035\end{array}$ \\
\hline Anemone biflora & Ranunculaceae & March-April & $\begin{array}{l}\text { Seed and } \\
\text { Rhizome }\end{array}$ & $\begin{array}{c}\text { Sorkheh, Shahbaz } \\
\text { mountain Aseman } \\
\text { valley }\end{array}$ & $\begin{array}{l}\text { Latitude: } 33^{\circ} 25^{\prime}-37^{\circ} 86^{\prime} \\
\text { Longitude: } 35^{\circ} 48^{\prime}-49^{\circ} 25^{\prime} \\
\text { Altitude: } 1861-2135\end{array}$ \\
\hline $\begin{array}{c}\text { Corydalis } \\
\text { verticillaris }\end{array}$ & Papaveraceae & March-April & Seed and Tuber & $\begin{array}{c}\text { Sorkheh, Shahbaz } \\
\text { mountain }\end{array}$ & $\begin{array}{l}\text { Latitude: } 33^{\circ} 25^{\prime}-34^{\circ} 34^{\prime} \\
\text { Longitude: } 40^{\circ} 40^{\prime}-4925^{\prime} \\
\text { Altitude: } 1861-2145\end{array}$ \\
\hline
\end{tabular}

The traits of length and width of calyx, length of petals, height of inflorescence, and length and width of flower were measured by Mm ruler, and the caliper was used to measure the bulb and rhizome, diameter of pedicel and diameter of stem. In this research, the characteristics of flower such as the number of flowers, length of petals, length of flowering stem, odor, length of flower, diameter of pedicel, length of calyx, width of calyx, height of inflorescence, and color of flower were recorded in the habitats. The traits such as the length of leaf, number of leaves and width of leaf were measured and the bulbs were removed from the soil and their lengths and widths were measured. The diameter and length of rhizome were measured for the rhizome species. The length of leaves was measured with Mm ruler and the diameter of bulbs and rhizomes were measured with a caliper. The code number was used for the odor, so that code number 1 belongs to flowers with odor and code number 0 belongs to flowers without odor. The colors were classified by code for the intensity of color where code number 1 belonged to the palest (white) and code number 6 belonged to the most chromatic (purple) flowers based on the color classification of Iris by Crişan et al. (2018). 
The seed production was calculated based on the number of seed capsules per inflorescence. All collected samples were identified according to the keys found in the plant flora (Wendelbo, 1977; Ghahraman, 1998; Al Maarri et al., 2017; Kandemir, 2019; Azimi at al., 2019, Azimi, 2021).

\section{Statistical analysis}

Statistical design used in this experiment was completely random with uneven duplicates. To analyze the variance of morphological features in the Iris ecotypes, the SAS software (version 9.1) was used. The Duncan Multiple Range Test (DMRT) was conducted to determine the significance of statistical difference between the average treatments. The descriptive statistics and simple correlation among features were done by SPSS software (version 16). The Pearson coefficient was used to calculate the correlation between the features. To obtain the genetic intervals and expected dendrogram, the PAST drawing software was used. The analysis of factors was done by SPSS software (version 16) and varimax technique. The coefficients above 1 were significant in each main and independent factor.

\section{Results}

In this research, the areas between the longitudes of $25^{\circ} 49^{\prime}$ and $73^{\circ} 50^{\prime}$ and latitudes of $52^{\circ} 33^{\prime}$ and $86^{\circ} 34^{\prime}$ were investigated. The five species of Iris including I. presica and I. hymernospatha Sub Spleptoneura from bulb species and I. mada, I. songarica, and I. spuria from rhizome species were identified. The I. persica includes 4 ecotypes, I. meda includes two ecotypes, and I. songarica includes seven ecotypes. Iris songarica Schrenk var. albitodo Ghahreman was identified for the first time in Markazi province, and so far, there have been no reports of such species in this area. The best time for collecting Iris sp. was the first week of April to early May for I. persica and I. hymernospatha. It was early May to early June for I. meda and I. songarica and early June to early July for I. spuria. A variety of $I$. songarica Schrenk var. albitodo Ghahreman was identified. Different colors were identified in I. songarica and $I$. persica (Figure 2 and Table 2).

In the assessed morphological characteristics, the highest coefficient of variation was related to the diameter of leafless stem (94.87) and the lowest coefficient of variation was related to seeding (0) (Table 2).
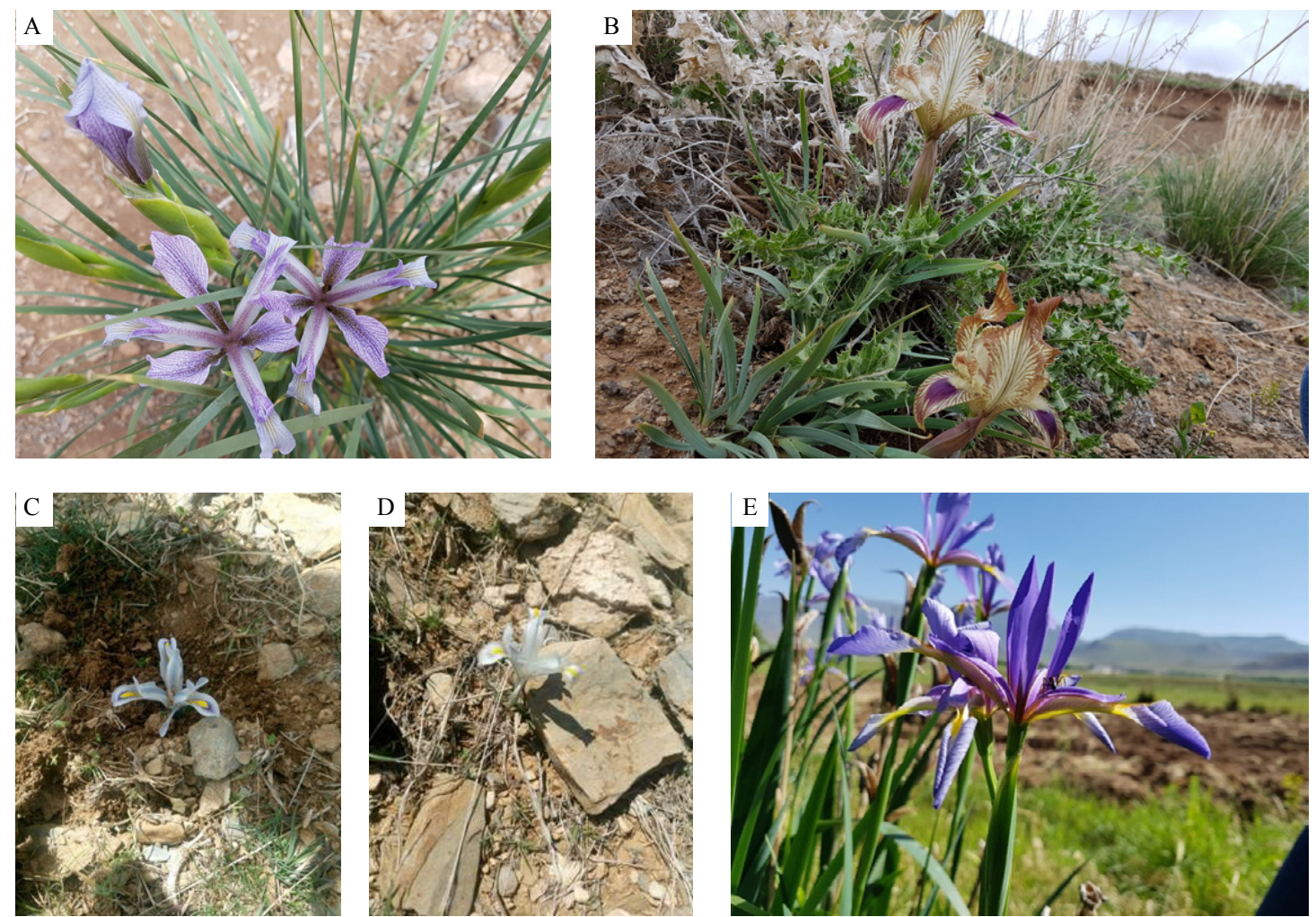

Figure 2. Species of Iris in Arak region A) I. songarica B) I. meda C) I. persica D) I. hymenospatha E) I. spuria 
Table 2. Descriptive statistics for morphological characters in the studied accessions of Iris.

\begin{tabular}{|c|c|c|c|c|c|c|c|c|}
\hline No. & Character & Abbreviation & Unit & min & max & Mean & sd & CV(\%) \\
\hline 1 & Number of flowers & nflo & number & 1 & 4 & 1.69 & 0.82 & 39.55 \\
\hline 2 & Petal length & pele & $\mathrm{cm}$ & 3 & 7.2 & 2.85 & 0.86 & 62.88 \\
\hline 3 & Calyx length & cale & $\mathrm{cm}$ & 0.07 & 5.5 & 1.4 & 0.97 & 50.47 \\
\hline 4 & Calyx width & cawi & $\mathrm{cm}$ & 0.1 & 2 & 0.31 & 0.31 & 66.42 \\
\hline 5 & Scent & Sce & code & 0 & 1 & 0.48 & 0.5 & 59.95 \\
\hline 6 & Flower height & inle & cm & 6.5 & 124 & 24.69 & 30.51 & 26.01 \\
\hline 7 & Diameter of peduncle & stdi & cm & 0.1 & 1.2 & 0.2 & 0.16 & 76.65 \\
\hline 8 & Flowering stem length & shle & $\mathrm{cm}$ & 1.3 & 38 & 9.62 & 7.97 & 63.03 \\
\hline 9 & Diameter of leafless stem & stle & $\mathrm{cm}$ & 0.168 & 3.82 & 0.78 & 0.32 & 94.78 \\
\hline 10 & Leaf lenght & lele & $\mathrm{cm}$ & 6 & 100 & 24.23 & 20.31 & 21.77 \\
\hline 11 & Leaf width & lewi & $\mathrm{cm}$ & 0.2 & 3.3 & 0.78 & 0.77 & 37.44 \\
\hline 12 & Number of leaf & nle & number & 2 & 17 & 4.89 & 2.45 & 37.45 \\
\hline 13 & bulb/rhizome length & blue & $\mathrm{cm}$ & 1 & 11.5 & 6.17 & 2.61 & 27.1 \\
\hline 14 & bulb/rhizome diameter & budi & $\mathrm{cm}$ & 0.6 & 2.7 & 1.34 & 0.53 & 18.91 \\
\hline 15 & Seed & see & \% & 8.8 & 95 & 55.37 & 32.37 & 0 \\
\hline
\end{tabular}

The results of correlation of traits showed that the highest positive correlation was between the height of the flower and the length of the leaf (0.94), the length of the flowering stem and the length of the leaf $(0.86)$ and the height of the flower and the length of the flowering stem (0.83), and in contrast, the highest negative correlation was obtained for the number of leaves and the diameter of bulb/rhizome (-0.42), the length of bulb/ rhizome and the length of calyx $(-0.37)$ and the width of bulb/rhizome and seeding $(-0.36)$. This means that the higher the flower height, the larger the diameter of the leafless stem and the higher the number of leaves, the lower the bulb/rhizome diameter (Table 3). The traits having a high coefficient of variation have a wider range of quantitative traits and are considered as the wider selection of the characteristics. The important traits such as the length of calyx, diameter of pedicel, length of flowering stem, length of petal, diameter of leafless stem, length of leaf, width of leaf, and odor have the highest diversity. 


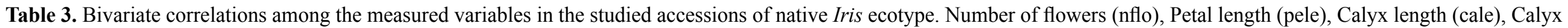

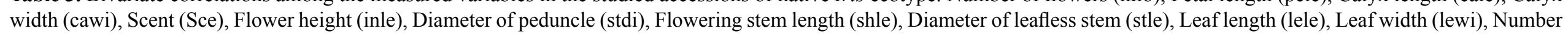
of leaf (nle), bulb/rhizome length (blue), bulb/rhizome diameter (budi), Seed (see)

\begin{tabular}{|c|c|c|c|c|c|c|c|c|c|c|c|c|c|c|c|}
\hline & nflo & Pele & Cale & cawi & sce & inle & stdi & shle & Stle & lele & lewi & nle & blue & budi & see \\
\hline Nflo & 1.00 & & & & & & & & & & & & & & \\
\hline Pele & $0.21^{* *}$ & 1.00 & & & & & & & & & & & & & \\
\hline Cale & $0.3^{* *}$ & $0.56^{* *}$ & 1.00 & & & & & & & & & & & & \\
\hline cawi & $0.18^{*}$ & $0.48^{* *}$ & $0.38^{* *}$ & 1.00 & & & & & & & & & & & \\
\hline Sce & $0.23^{* *}$ & $0.41^{* *}$ & $0.24^{* *}$ & $0.51^{* *}$ & 1.00 & & & & & & & & & & \\
\hline Inle & $0.19^{*}$ & $0.54^{* *}$ & $0.32^{* *}$ & $0.7^{* *}$ & $0.45^{* *}$ & 1.00 & & & & & & & & & \\
\hline Stdi & $0.35^{* *}$ & $0.3^{* *}$ & $0.44^{* *}$ & $0.47^{* *}$ & $0.29^{* *}$ & $0.37^{* *}$ & 1.00 & & & & & & & & \\
\hline Shle & $0.25^{* *}$ & $0.64^{* *}$ & $0.55^{* *}$ & $0.62^{* *}$ & $0.34^{* *}$ & $0.83^{* *}$ & $0.38^{* *}$ & 1.00 & & & & & & & \\
\hline Stle & -0.007 & 0.16 & 0.03 & $0.21^{* *}$ & $0.18^{*}$ & $0.18^{*}$ & 0.12 & 0.12 & 1.00 & & & & & & \\
\hline Lele & $0.2^{*}$ & $0.52^{* *}$ & $0.34^{* *}$ & $0.64^{* *}$ & $0.35^{* *}$ & $0.94^{* *}$ & $0.29^{* *}$ & $0.86^{* *}$ & 0.11 & 1.00 & & & & & \\
\hline Lewi & 0.03 & 0.2 & 0.14 & $0.37^{* *}$ & $0.21^{*}$ & $0.71^{* *}$ & 0.09 & $0.45^{* *}$ & $0.24^{* *}$ & $0.63^{* *}$ & 1.00 & & & & \\
\hline Nle & 0.14 & 0.02 & $0.21^{* *}$ & 0.09 & $0.31^{* *}$ & 0.07 & 0.15 & 0.02 & 0.05 & 0.09 & 0.16 & 1.00 & & & \\
\hline Bule & $0.07^{* *}$ & 0.16 & 0.13 & 0.04 & $0.27^{* *}$ & 0.14 & 0.01 & $0.25^{* *}$ & 0.01 & $0.23^{* *}$ & $0.21^{* *}$ & $-0.18^{*}$ & 1.00 & & \\
\hline Budi & -0.37 & -0.04 & $-0.37^{* *}$ & -0.05 & $-0.17^{*}$ & $0.24^{* *}$ & $-0.24^{* *}$ & 0.06 & 0.04 & $0.24^{* *}$ & $0.66^{* *}$ & $-0.42^{* *}$ & $0.42^{* *}$ & 1.00 & \\
\hline See & $0.42^{* *}$ & $0.63^{* *}$ & $0.68^{* *}$ & $0.72^{* *}$ & $0.63^{* *}$ & $0.6^{* *}$ & $0.6^{* *}$ & $0.7^{* *}$ & $0.2^{*}$ & $0.55^{* *}$ & 0.12 & $0.25^{* *}$ & -0.01 & $-0.36^{* *}$ & 1.00 \\
\hline
\end{tabular}


According to the cluster diagram, the ecotypes are divided into 6 groups in the interval of 15 Euclid where the both ecotypes of $I$. meda are in the same group. The genotype of white and blue-white I. songarica collected from Amirkabir Shahrak area, purple-white collected from Amrabad and white-purple collected from Amirkabir Shahrak all had the traits in common. The most common characteristics were the flower number, length of petal, width of calyx, odor, length of flowering stem, length of leaf, width of leaf, number of leaves and amount of seeding. The purple-white, pink and pinkwhite I. songarica all collected from Amirkabir Shahrak were in the same group and had common features that make them close to each other. The purple-white color of I. songarica, I. songarica 2, and I. songarica 3 were categorized into two separate groups considering having the same color. I. persica from Shahbaz area, I. persica from Tafresh, I. persica from Aseman valley, I. persica from Gerdoo mountain, I. hymernospat from Aseman valley and $I$. persica from Haftad Ghole all had common traits, especially the length of stem and width of leaf. Iris persica 2 from Cheshmeh Sarab, I. persica from Daen, Iris persica from Ghaynarogh, Iris persica from Hezaveh, Iris persica from Gerdo mountain and Iris hymernospata from Daen had more common features and closer relationship (Figure 3 ).

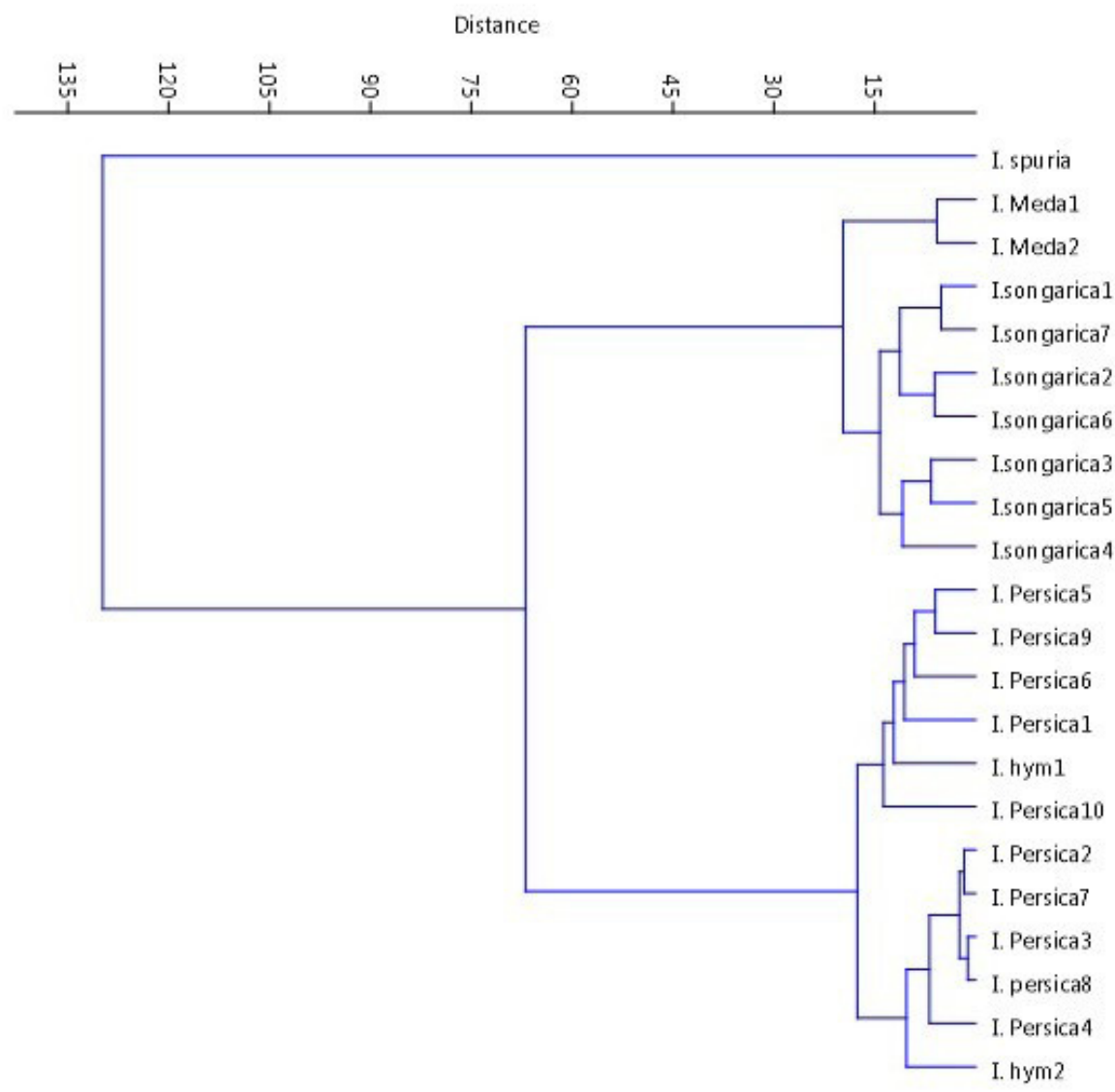

Figure 3. Dendrogram of cluster analysis for the studied accessions of Iris sp. Based on morphological traits.

The results of the analysis divided the morphological data into 4 factors (Tables 4 and 5). These four factors could justify $84.79 \%$ of total variance. In the first factor, the traits of petal length, height of flower, seeding, number of flowers, length and width of calyx had a higher coefficient and justified $45 \%$ of the total variance. In the second factor, the features of odor, length of bulb and number of leaves justified $19 \%$ of the total variance. In the third factor, the features of bulb diameter, width of leaf and diameter of leafless stem justified $11 \%$ of the total variance. In the fourth factor, the feature of pedicel justified $7 \%$ of the total variance. 
Table 4. Principle component analysis (PCA) for morphological traits in Iris sp.

\begin{tabular}{|c|c|c|c|}
\hline Factors & $\begin{array}{c}\text { Cumulative percentage of } \\
\text { variance }\end{array}$ & Eigenvalues in percent & Variance of eigenvalues \\
\hline 1 & 6.97 & 46.52 & 46.52 \\
\hline 2 & 2.89 & 19.26 & 65.78 \\
\hline 3 & 1.68 & 11.25 & 77.03 \\
\hline 4 & 1.16 & 7.75 & 84.79 \\
\hline 5 & 0.78 & 5.21 & 90 \\
\hline 6 & 0.46 & 3.1 & 93.11 \\
\hline 7 & 0.34 & 2.3 & 95.41 \\
\hline 10 & 0.26 & 1.79 & 97.21 \\
\hline 11 & 0.14 & 0.96 & 98.7 \\
\hline 12 & 0.1 & 0.7 & 98.87 \\
\hline 14 & 0.07 & 0.49 & 99.37 \\
\hline 15 & 0.05 & 0.38 & 99.75 \\
\hline
\end{tabular}

Table 5. Factor coefficient after rotation of Verimax for 4 main factors. Number of flowers (nflo), Petal length (pele), Calyx length (cale), Calyx width (cawi), Scent (Sce), Flower height (inle), Diameter of peduncle (stdi), Flowering stem length (shle), Diameter of leafless stem (stle), Leaf length (lele), Leaf width (lewi), Number of leaf (nle), bulb/rhizome length (blue), bulb/rhizome diameter (budi), Seed

\begin{tabular}{|c|c|c|c|c|}
\hline Traits & $\mathbf{1}$ & $\mathbf{2}$ & $\mathbf{3}$ & $\mathbf{4}$ \\
\hline Pele & 0.82 & 0.34 & -0.12 & -0.12 \\
\hline Lele & 0.82 & 0.03 & 0.42 & 0.12 \\
\hline Inle & 0.75 & 0.06 & 0.55 & 0.03 \\
\hline Sce & 0.56 & 0.71 & 0.21 & 0.06 \\
\hline Blue & 0.22 & -0.85 & 0.07 & -0.23 \\
\hline Budi & -0.38 & -0.54 & 0.59 & 0.06 \\
\hline Nle & 0.21 & 0.83 & -0.12 & 0.1 \\
\hline Lewi & 0.05 & -0.16 & 0.95 & 0.15 \\
\hline See & 0.92 & 0.25 & -0.15 & 0.44 \\
\hline Nflo & 0.53 & 0.44 & -0.13 & 0.16 \\
\hline Cale & 0.85 & 0.01 & -0.4 & 0.11 \\
\hline Cawi & 0.91 & 0.19 & 0.12 & 0.91 \\
\hline Stdi & 0.04 & -0.05 & 0.05 & 0.05 \\
\hline Shle & 0.9 & -0.16 & 0.16 & 0.54 \\
\hline Stle & 0.24 & 0.2 & 0.54 & \\
\hline
\end{tabular}

According to the plot diagram (Figure 4), the ecotypes of the found Iris sp. were divided into four groups according to the justifying traits. The first group included Iris persica collected from Shahbaz mountain area, Iris persica collected from Gerdo Mountain, and Iris hymernospatha collected from Aseman valley. 


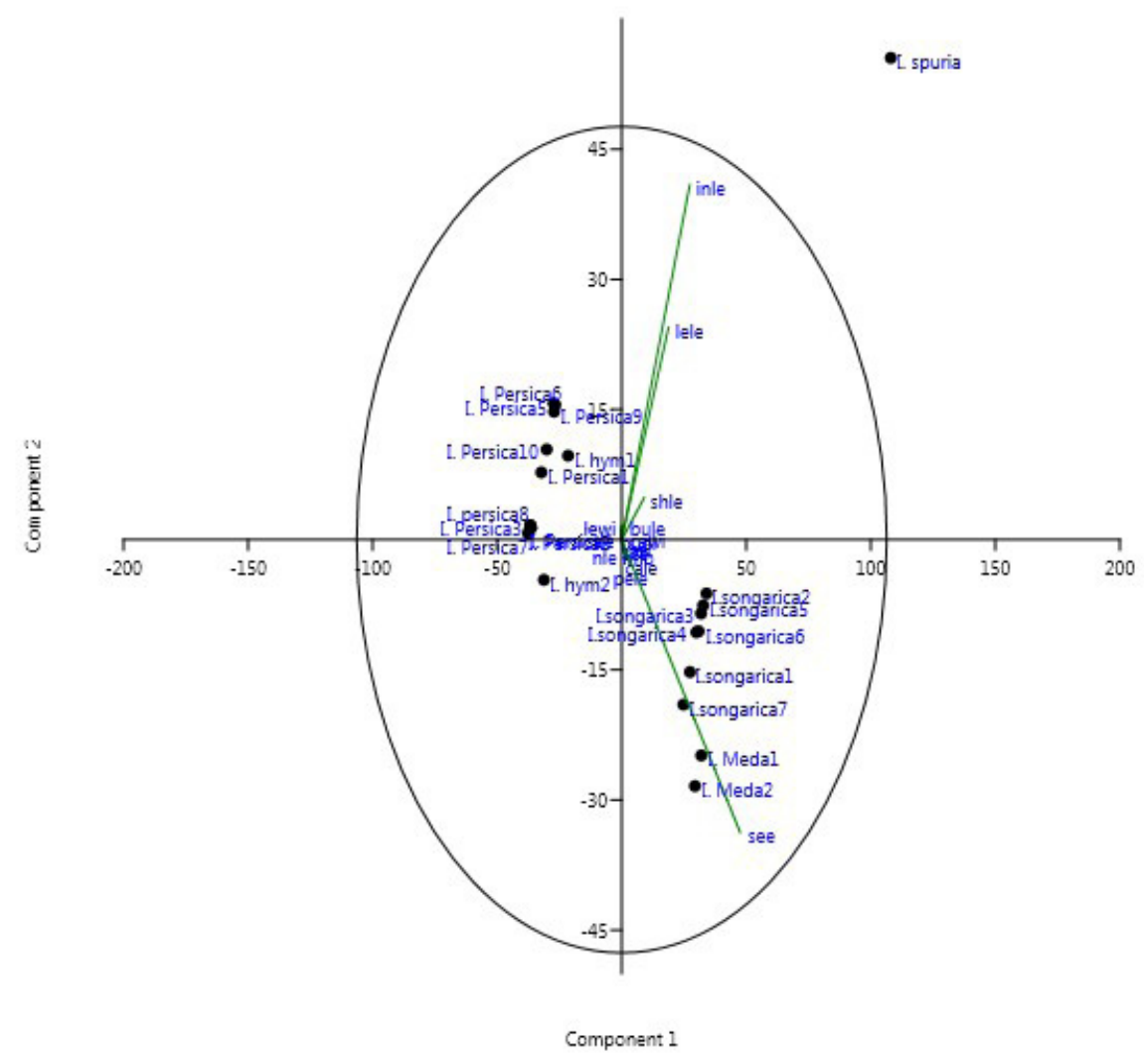

Figure 4. Two-dimensional scatter plot for the first two principal components (PC1/PC2, 24.41\% of the total variability) for the studied accessions of I. sp.

The second group included Iris persica collected from Cheshmeh Sarab, Iris persica collected from Daen, Iris persica collected from Ghanarough, Iris persica collected from Hezaveh, Iris persica collected from Gerdo mountain, and Iris hymernospatha collected from Daen. The third group included white Iris songarica, purplewhite Iris songarica of Amrabad area, Purple-white Iris songarica of Amirkabir town, pink Iris songarica, pinkwhite Iris songarica, white-purple Iris songarica, whiteblue Iris songarica, creamy and a little purple Iris meda, and yellow-purple Iris meda. The fourth group including Iris spuria independently formed a group.

\section{Discussion}

According to the observations during this research, the rhizome species were found in different areas from high mountains to vast sandy plains or different swamps and ponds, but the bulb species were only found in the mountain areas. Based on observational findings, different insects lived around the rhizome species, especially the ants had nests where Iris songarica grew. Considering the found colorful diversity of this species and the existence of many insects, it can be stated that this species had many other ways of pollination and included different varieties that have not yet been identified. Five species were identified in Arak and surroundings where Iris persica species includes four ecotypes, Iris meda includes two ecotypes, and Iris songarica includes seven ecotypes consisting of six colors. For the first time, Iris songarica Schrenk var. albitodo was identified in Arak and it was already identified by
Ghahraman in Shiraz in 1998 and found in Amirkabir area in our research. Similarly, Beiramizadeh (2009) identified 9 species, but the species were not mentioned. Also, Rahimi et al. (2011) mentioned one species for Markazi province in 2011 and Azimi et al. 2019 mentioned one species for Markazi province, and we also identified these species.

The diversity in different characteristics shows the enriched germplasm of this bulbous plant for the breeding of the desired traits to develop, increase in the efficiency, and commercial exploitation. The results showed that there is a correlation between some of the traits. The highest positive correlation was related to the height of flower and length of leaf, length of leaf and length of petal, number of leaf and length of leaf, length of flowering leaf and length of leaf, and flower height and length of flowering stem, which was consistent with the results of Azimi et al. (2016) and Roueen et al. (2015). The coefficient of correlation between the length of stem and the size showed that there is a direct relationship between the length of stem and the leaf size, so that the genotypes with higher height produced larger leaves (Roueen et al., 2015; Azimi and Banijamali, 2019).

Also, our results were consistent with other bulbous species such as shallots. According to the results of Hosseini et al. (2017) on the shallots, the correlation between the height of stem and the length and width of leaf was positive and significant, that is, with increasing the leaf length and width, the stem height can be increased. The highest negative correlation was related to the length of leaf and the length of bulb/rhizome with the length of calyx and diameter of bulb/rhizome and seeding. Most 
likely, the diameter and length of bulb/rhizome affect the morphology of aerial organs. They have been rarely mentioned so far and the results were inconsistent with the results of Kapczynska (2014) who stated that the average produced leaves in the $5.1-6 \mathrm{~cm}$ bulbs were similar to larger bulbs, but the number of produced leaves in the bulbs less than $5 \mathrm{~cm}$ were significantly less than other bulbs. There were not many differences between the species in the traits related to leaf.

There were not many differences between the species in the traits related to leaf. The obtained results in the morphological diversity of native Iris sp. of Iran showed that there were significant differences between all the studied qualitative traits where the highest phonotype diversity was observed for the feature of leaf width (Rahimi et al., 2011). The studied species of Iris had significant differences in the most characteristics that were consistent with the findings of Azimi et al. (2018), Azimi (2021), Rahimi et al. (2011) and Abroshan et al. (2017).

According to the cluster diagram, the ecotypes were divided into six groups in the interval of 15 Euclid where the both colors of Iris meda species are in the same group. The white and blue-white Iris singarica collected from Amirkabir, purple-white collected from Amrabad and white-purple collected from Amirkabir all had traits in common and the most common features were the number of flowers, length of petal, width of calyx, odor, length of flowering stem, length of leaf, width of leaf, number of leaves, and amount of seeding.

The purple-white, pink and pink-white Iris songarica collected from Amirkabir were grouped and have common characteristics that make them close to each other. The purple-white colors of Iris songaric, Iris songarica 2, and Iris songarica 3 were divided into two separate groups which can be due to the environment effects, geographical area and climate of the habitat of two different areas. Kandemir (2019) found that the natural selection (including weather conditions and geographical separation) caused the differentiation among the populations.

Based on the results of the cluster diagram, the bulbous species were separated from rhizome species. As was found from the Azimi et al. (2019) results, the cluster analysis based on the quantitative traits can separate the rhizome Iris sp. from bulbous Iris $\mathrm{sp}$. as qualitative traits. Iris spuria was not mentioned in the Ghahraman colorful flora in Arak, but the identification of this species in Poldoab was mentioned in a research in 2016, and we identified this species around the village of Far.

\section{Conclusions}

Generally, because of color diversity of Iris sp. and unique beauty of the flowers and the resistance of the native species, they can be used as native foundations. Due to the prominent traits such as high durability of Iris meda, odor of I. hymernospatha Subsp. leptoneura and color diversity of I. persica, I. songarica and height of I. spuria, they can be used to introduce new ornamental species. Also, considering the beauty of Iris persica, Iris meda, Iris songarica, and Iris spuria flowers, they can be introduced as ornamental flowers among which Iris spuria is the most suitable genotype because of the high height, large flower, high durability, and beautiful flower.

\section{Acknowledgments}

The authors are grateful to Arak University for supporting this work under research.

\section{Author Contribution}

MT: participated in all of experiments, coordinated the dataanalysis and contributed to the writing of the manuscript. EA: Coordinated the farm work and writing of the manuscript. ARA: Coordinated the farm work and reviewing of the manuscript.

\section{References}

ABROSHAN, M.; ZAHEDI, B.; SIAH MANSOUR, R. Morphological variation of Fritillaria imperialis $\mathrm{L}$ in five regions of Lorestan Province. Iranian Journal of Horticultural Science, v.48, n.1, p.9-1, 2017.

AL MAARRI, K.H.; ABOU ZEDAN, T.H.; AL BATAL, N. Wild golden Iris (Iris aurantica) in Syria. Current Trends in Biomedical Engineering \& Biosciences, v.1, n.5, p.555573, 2017.

ATTARI, Z.; SHOOR, M.; GHORBANZADEH NIQAB, M.; TEHRANI FAR, A.; MALEKZADEH SHAFAROODI, S. Evaluation of genetic diversity of Iris genotypes (Iris spp) using ISSR. Journal of Horticultural Sciences (Food Science), v.30, p.382-376, 2016. https://doi.org/10.22067/ JHORTS4.V30I3.28044

AZIMI, M.; SADEGHIAN MOTAHAR, Y.; BIRAMIZADEH, A.; SADEGHI, L. Investigation of genetic diversity of some Iranian iris species using RAPD markers. Iranian Journal of Horticultural Science and Technology, v.12, n.1, p.95-85, 2011.

AZIMI, M.; TEHRANZADEH, Z.; ZAMANI, M. Genetic variation within Iranian Iris species using morphological traits. International Journal of Horticultural Science and Technology, v.3, n.1, p.89-98, 2016.

AZIMI, M.H. Evaluation of heterosis and important traits in new hybrids of Iris germanica in F1. Journal of Horticulture and Postharvest Research, v.4, n.2, p.231$242,2021$.

AZIMI, M.H.; BANIJAMALI, S.M. Introducing superior cultivars of Gladiolus by important quality and quantity indexes. Journal of Ornamental Plants, v.9, n.1, p. 33-40, 2019. 
AZIMI, M.H.; JOZGHASEMI, S.; HASANZADEH DAVARANI, F.; ALIABADI, H.M. A review of Iranian Iris germplasm. International Symposium on Wild Flowers and Native Ornamental Plants, v.1, n.20, p.51-56, 2019. https://doi.org/10.17660/ActaHortic.2019.1240.8

BEIRAMIZADEH, A. Final report of the project for collecting, identifying and evaluating the inherited reserves of Iris and Gladiolus in Iran for use and protection. National Research Station for Flowers and Ornamental Plants (Mahalat), 2009. p.100.

CRIŞAN, I.; VIDICAN, R.; MOREA, A.; SIMEA, Ş. Dyeing potential of linen fabric with Iris flower extracts. ProEnvironment, v.11, n.36, p. 223-227, 2018.

DEMIR, S.; CELIKEL, F.G. A study on plant height control of Iris Flowers. Agrofor, v.3, n.3, p.131-141, 2018.

GHAHRAMAN, A. Iran Color Flora. Iran: Institute for Research and Rangeland 18, 1998. p.1055-1200.

HOSSEINI, A.M.; TEHRANI FAR, A.; SAMIEI, L.; SHOR, M.; MEMARIANI, F. Collection and evaluation of morphological diversity of some species of allium (L. Allium) native to Khorasan. Journal of Horticultural Science, v.30, n.4, p.701-713, 2017.

HOSSEINI, A.S.; AKRAMIAN, M.; KHADIVI, A.; SALEHI-ARJMAND, H. Phenotypic and chemical variation of black mulberry (Morus nigra) genotypes. Industrial Crops and Products, v.117, p.260-271, 2018. https://doi.org/10.1016/j.indcrop.2018.03.007

KANDEMIR, N. Comparative morphological and anatomical studies on Iris peshmeniana Güner \& T. Hall. and Iris aucheri (Baker) Sealy (Iridaceae). Trakya University Journal of Natural Sciences, v.20, n.2, p.105-113, 2019.

KANDEMIR, N.; KHAN, G.; CELIK, A. Comparative morphological and anatomical and ecological studies on two varieties of Iris unguicularis subsp. carica (Iridaceae) in Turkey. Planta Daninha, v.37, p.1-12, 2019.

KAPCZYNSKA, A. Effect of bulb size on growth, flowering and bulb formation in lachenalia cultivars. Horticultural Science, v.41, n.2, p.89-94, 2014. https:// doi.org/10.17221/183/2013-HORTSCI

KHAKIZADEH, G.H.; GHANAVATI, F. Biodiversity of Iris species in Hamadan Province. Urmia: National Conference on Biodiversity and its Impact on Agriculture and Environment, 2010.
KIANI, M.; MOHAMMADI, S.H.; BABAEI, A.R.; SEFIDKON, F.; NAGHAVI, M.R.; RANJBAR, M.; RAZAVI, A.; SAEIDI, K.A.; JAFARI, H.; ASGARI, D.; POTTER, D. Iran supports a great share of biodiversity and floristic endemism for Fritillaria spp. (Liliaceae): A review. Plant Diversity, v.39, p.245-262, 2017.

MOSA, K.A.; GAIROLA, S.; JAMDADE, R.; ELKEBLAWY, A.; AL SHAER, K.I.; AL HARTHI, E.K.; SHABANA, H.A.; MAHMOUD, T. The promise of molecular and genomic techniques for biodiversity research and DNA barcoding of the Arabian Peninsula Flora. Fronteirs in Plant Science, v.9, p.1929, 2019. https://doi. org/10.3389/fpls.2018.01929

NOMAN, A.; AQEEL, M.; DENG, J.; KHALID, N.; SANAULLAH, T.; SHUILIN, H. Biotechnological advancements for improving floral attributes in ornamental plants. Frontiers in Plant Science, v.8, p.530, 2017. https://doi.org/10.3389/fpls.2017.00530

PARVIN, M.R.; ALIZADEH, F. Sustainable development of essential plant genetic resources at the same time in the development and support of biotechnology and conservation of biodiversity. Gorgan: National cooperation of human rights with regard to environmental challenges in the northern regions of the country, 2017.

RAHIMI, V.; SADAT-HOSSEINI, GROUH; SOLYMANI, M.; BAHERMAND, A.; MEFTAHIZADE, N. Assessment of cytological and morphological variation among Iranian native Iris species. African Journal of Biotechnology, v.10, n.44, p.8805-8815, 2011.

ROUEEN, Z.; HASSANPOUR, A.S.L.M.; SABURI, A.S. Investigation of morphological traits, genetic evaluation and grouping of chrysanthemum genotypes. Journal of Production and Processing of Crop and Horticultural Products, v.16, p.359-345, 2015.

SCHAI-BRAUN, S.C.; LAPIN, K.; BERNHARDT, K.J.; ALVES, P.C.; HACKLÄNDER, K. Effect of landscape type, elevation, vegetation period, and taxonomic plant identification level on diet preferences of Alpine mountain hares (Lepus timidus varronis). European Journal of Wildlife Research, v.66, p.57, 2020.

SINGABA, A.N.B.; AYOUB, I.M.; EL-SHAZLYA, M.; KORINEK, M.; TUNG-YING, W.; YUAN-BIN, CH.; FANG-RONG, CH.; YANG-CHANG, W. Shedding the light on Iridaceae: Ethnobotany, phytochemistry and biological activity. Industrial Crops and Products, v.92, p.308-335, 2016. 
VAN DER PLOEG, A.; HEUVELINK, E. The influence of temperature on growth and development of chrysanthemum cultivars: A review. The Journal of Horticultural Science and Biotechnology, v.81, p.174-182, 2006.

WENDELBO, P. Tulips and irises of Iran and neighboring species. Botanical Garden, Iran, p.81-68, 1977.

WENDELBO, P.; MATHEW, B. Iridaceae, Flora of Iranian Highlands. Graz: Akademische Druck-u Verlaganstalt, 1975.
YANG, Z.; TONGFEI, M.; XIAOYING, B.; JIAJUN, L. Investigation and evaluation of wild Iris resources in Liaoning Province, China. Genetic Resource Crop, v.64, p.967-978, 2017.

YUVAL, S.; AVI, S.; ORI, F.; PETER, C. Morphological variation of the Oncocyclus Iirises (Iris:Iridaceae) in the southern Levant. Botanical Journal of the Linnean Society, v.139, p.369-382, 2002. 